Article

\title{
Provision of Public Health Services and Sustainable Development: Evidence for 12 Emerging Countries
}

\author{
Oscar Bajo-Rubio ${ }^{1, *(1)}$ and Antonio G. Gómez-Plana ${ }^{2}$ (D) \\ 1 Department of Economics, Universidad de Castilla-La Mancha, Ronda de Toledo s/n, \\ 13071 Ciudad Real, Spain \\ 2 Department of Economics and INARBE, Universidad Pública de Navarra, Campus de Arrosadía s/n, \\ 31006 Pamplona, Spain; agomezgp@unavarra.es \\ * Correspondence: oscar.bajo@uclm.es
}

Received: 26 June 2020; Accepted: 11 August 2020; Published: 13 August 2020

\begin{abstract}
In this paper, we quantify the effects of an increase in the public provision of health services in a set of 12 emerging economies (i.e., Brazil, Chile, China, Colombia, India, Kazakhstan, Mexico, Morocco, Peru, Russia, South Africa and Tunisia), representing 45\% of world population in 2018. We use a computable general equilibrium model and simulate an increase in the real government expenditure devoted to public health services up to a $20 \%$ of total government expenditure, which is also assumed to raise labour productivity. This increase leads to expansionary effects in terms of gross domestic product (GDP) and employment for all the economies under analysis and an increase in the ratio of government deficit to GDP, ranging between 3.66 points for Russia and 0.24 points for Colombia. If, in addition, direct tax rates on labour are increased to offset this result, the effects on GDP and employment become contractionary in most cases; whereas if indirect tax rates are those to be increased, small expansionary effects are again the norm with the only exception of Russia.
\end{abstract}

Keywords: Sustainable Development Goals; spending in health services; computable general equilibrium

\section{Introduction}

In 2015 the United Nations General Assembly established the Sustainable Development Goals (SDGs), i.e., a collection of 17 global goals designed to achieve a more sustainable future for the planet. These SDGs are intended to be met by 2030, in the context of the 2030 Agenda for Sustainable Development. The main aim of the 2030 Agenda is achieving sustainable development in three dimensions, namely, economic, social and environmental, in a balanced and integrated way (see United Nations [1]).

Within these 17 SDGs, number 3 is "Ensure healthy lives and promote well-being for all at all ages". Improving health conditions is a pre-requisite for a proper standard of living for many people in the world. Accordingly, the 2030 Agenda seeks to achieve universal health coverage, by promoting actions in several fields such as increasing life expectancy and reducing child and maternal mortality, favouring access to clean water and sanitation, and fighting some diseases still common in poor countries. In addition, it envisages to increase health financing and the recruitment, training and retention of the health workforce in poorer countries; see United Nations [1] for more details. Overall, this set of measures, by enhancing the well-being of population, should result in a more sustainable development of the planet as a whole.

In this paper, we will try to quantify the effects of an increase in the public provision of health services in a set of emerging economies. In a related paper (Bajo-Rubio and Gómez-Plana [2]), we followed a similar approach focusing on the case of China and its effects on the world economy; unlike the present paper, where we analyse the case of a set of emerging countries and its effects on their own economies. 
As an additional difference, in this paper we modify the model so that labour productivity rises in the countries analysed following the increased public expenditure in health services; see below. On the other hand, a higher spending in health services should lead to greater public deficits, so we will also analyse two cases where taxes rise to counterweigh those larger deficits, i.e., through an increase in direct taxes on labour and in indirect taxes, respectively. The analysis is based on a computable general equilibrium (CGE) model. These models are widely used for policy analysis in fields such as fiscal policies, trade policies, environmental policies and so on. In particular, World Health Organization [3] discusses the appropriateness of CGE models for the analysis of the economic impact of health-related issues and offers some specific examples. The theoretical basis of the standard CGE models is Arrow-Debreu's general equilibrium, and the main advantage of such models is that they allow obtaining the effects of variations in a particular variable or parameter on the whole economy under analysis, as well as the interactions across markets and sectors. As limitations of these models, we can mention that the elasticities of substitution in production and welfare functions are usually taken from the literature, instead of being estimated. Also, as Walrasian models, the monetary side of the economy is underrepresented and the financial sector is only modelled using its real variables. A detailed discussion of CGE modelling is provided in, e.g., Shoven and Whalley [4], Dixon and Jorgenson [5] or Burfisher [6].

Regarding the choice of the countries to be analysed, ideally, all non-developed countries should be included; however, we are constrained by data requirements in a general equilibrium context. A database with a worldwide coverage is that developed at the Global Trade Analysis Project (GTAP, see below), which includes a large set of economic variables in a general equilibrium and National Accounts framework. However, GTAP does not incorporate all the necessary data, especially in variables related to the public sector closure. Using national public sector data within a unified methodology across countries has been considered mandatory and, as far as we know, the United Nations' National Account Statistics is the best source for this (see details in Section 2). The drawback of this option is that the number of non-developed countries included in the analysis is reduced, due to the lack of data for many countries, so we have taken a sample of 12 emerging countries for which all the requested data are available. These 12 economies represent a population of 3.4 billion people out of 7.6 billion (i.e., $45 \%$ of world population in 2018, according to World Bank data). This share of the world population has been considered appropriate for the aims of the present analysis.

There are some studies available that analyse the main drivers of health spending. Although most of them refer to developed countries, most determinants are common, such as differences in income (basically gross domestic product (GDP) per capita), demographic factors (especially population age structure), technological progress (involving a higher spending in new technologies and medicines for medical treatments), or health system characteristics such as service provision (e.g., by the public sector), financing (e.g., systems based on taxes or on social insurance), external funds (in the form of official development aid) and so on; see Xu et al. [7] for a more detailed account. All these factors would explain the differences in health spending across countries.

In Table 1 we present three indicators related to health spending, namely, (i) total health expenditure as a percentage of GDP, (ii) general government health expenditure as a percentage of GDP, and (iii) general government health expenditure as a percentage of the total general government expenditure, for a selection of 10 developed countries (6 European: France, Germany, Italy, Spain, Sweden and the United Kingdom; plus Australia, Canada, Japan and the United States) and the 12 emerging countries that are the object of this paper (Brazil, Chile, China, Colombia, India, Kazakhstan, Mexico, Morocco, Peru, Russia, South Africa and Tunisia); the data refer to the last year available, i.e., 2017. Beyond the heterogeneity of the different countries' experiences, a result clearly emerges, i.e., the lower government involvement in providing health protection in emerging economies. As can be seen in the table, while some of the developing countries (e.g., Brazil, Chile or South Africa) have a ratio of total health expenditure to GDP comparable to those of the developed countries, when considering the ratio of the government health expenditure to GDP all of them are clearly below. Finally, when looking at the ratio of the government health expenditure to the total government expenditure, the results are 
not so clear-cut; even so, developed countries show in general larger figures, above $20 \%$ in Japan and the United States, and not far in several countries (such as Australia, Canada, Germany, Sweden and the United Kingdom), with the rest of countries showing ratios close to 15\%. Summarising, emerging countries, such as those analysed in this paper, show a lower public involvement in the provision of health services; in those countries with a total health expenditure closer to that of developed countries, this is due to the contribution of the private sector, which presumably does not extend to broad segments of the population, especially, e.g., for poorer people or for residents in rural areas.

Table 1. Some indicators of health expenditure in selected countries, 2017.

\begin{tabular}{cccc}
\hline Current Health & $\begin{array}{c}\text { General Government } \\
\text { Expenditure as } \\
\text { \% of GDP }\end{array}$ & $\begin{array}{c}\text { Health Expenditure as } \\
\text { \% of GDP }\end{array}$ & $\begin{array}{c}\text { General Government Health } \\
\text { Expenditure as \% of General } \\
\text { Government Expenditure }\end{array}$ \\
\hline $\begin{array}{c}\text { Developed countries } \\
\text { Australia }\end{array}$ & 9.2 & 6.3 & 17.8 \\
Canada & 10.6 & 7.8 & 19.3 \\
France & 11.3 & 8.7 & 15.5 \\
Germany & 11.2 & 8.7 & 19.9 \\
Italy & 8.8 & 6.5 & 13.4 \\
Japan & 10.9 & 9.2 & 23.6 \\
Spain & 8.9 & 6.3 & 15.3 \\
Sweden & 11.0 & 9.2 & 18.7 \\
United Kingdom & 9.6 & 7.6 & 18.7 \\
United States & 17.1 & 8.6 & 22.5 \\
Emerging countries & & & \\
Brazil & 9.5 & 4.0 & 10.3 \\
Chile & 9.0 & 4.5 & 17.7 \\
China & 5.2 & 2.9 & 9.1 \\
Colombia & 7.2 & 4.9 & 17.5 \\
India & 3.5 & 1.0 & 7.4 \\
Kazakhstan & 3.1 & 1.9 & 7.9 \\
Mexico & 5.5 & 2.8 & 7.0 \\
Morocco & 5.2 & 2.3 & 14.9 \\
Peru & 5.0 & 3.2 & 8.8 \\
Russia & 5.3 & 3.1 & 13.3 \\
South Africa & 8.1 & 4.4 & 13.6 \\
Tunisia & 7.2 & 4.1 & \\
\hline
\end{tabular}

GDP, gross domestic product. Source: World Health Organization, Global Health Expenditure Database.

In short, given that emerging countries show a lower public involvement in the provision of health services, and that better health conditions make up one of the United Nations' SDGs, a higher public provision of health services should result in a more sustainable growth in those countries.

The model we use is an extension of the GTAP model. GTAP is a global network of researchers (from universities, international organisations or national governments) aimed to conduct quantitative analyses of international economic policy issues, including trade policy, climate policy and several issues related to globalisation; for more information, see the GTAP website at https://www.gtap.age con.purdue.edu. The core of GTAP is a data set for the world economy, involving an input-output framework together with bilateral trade flows. The GTAP project is coordinated by a team based in the Agricultural Economics Department at Purdue University, in West Lafayette, Indiana, United States of America.

The rest of the paper is organised as follows: a brief description of the model is provided in Section 2, the data and calibration process are discussed in Section 3, and the results from the simulations are presented in Section 4. Finally, the main conclusions are summarised in Section 5.

\section{The Model}

The model used in this paper follows Bajo-Rubio and Gómez-Plana [2], which is in turn an extension of Lanz and Rutherford [8]. It is a CGE model with 13 open economies (i.e., 12 countries and another one representing the rest of the world), with 7 productive sectors, 1 representative household 
and a government sector for each country, as well as 3 primary factors (i.e., labour, capital and natural resources). The countries and sectors are listed in Table 2.

Table 2. Countries and sectors.

\begin{tabular}{cc}
\hline Countries & Sectors \\
\hline Brazil & Agriculture \\
Chile & Mining \\
China & Energy \\
Colombia & Industry \\
India & Construction \\
Kazakhstan & Government services \\
Mexico & Other services \\
Morocco & \\
Peru & \\
Russia & \\
South Africa & \\
Tunisia & \\
Rest of the World & \\
\hline
\end{tabular}

Specifically, the original model GTAP9inGAMS (see Lanz and Rutherford [8]) has been extended as follows:

(1) The original model includes one representative agent for each country or region. In our model, this representative agent has been divided into two agents, i.e., the government sector and a representative private household, which involves changes in equations and data. To that end, National Accounts and other data sources external to the GTAP database have been used for the new microeconomic and macroeconomic variables.

(2) The original GTAP9inGAMS takes as exogenous both public expenditure and national savings (i.e., the aggregate of private and public savings). In our version, the inclusion of the government sector is accompanied with the assumption of endogenous public expenditure and public savings in the different scenarios. In particular, the share of public expenditure related to health services (i.e., our variable of interest when performing the simulations) is always assumed to be endogenous, but the rest of public expenditure does not change. In turn, public savings are endogenous in the scenario where the government deficit is assumed to be endogenous but are kept constant in the other two scenarios (see the next section for the definition of the three scenarios).

(3) The original model assumes full employment in labour markets. However, given that most countries experience high unemployment rates, our version includes unemployment at national level following the wage curve models.

(4) In the original GTAP9inGAMS the trade balance is assumed to be exogenous. However, in our version the trade balance is endogenous at national level, which allows for broader international linkages.

The system of equations of the model defines a general equilibrium. The general equilibrium model is described as a mixed complementarity problem (see Mathiesen [9]) and is solved as explained in Rutherford [10], using the software GAMS/MPSGE (i.e., a high-level modelling system for solving general equilibrium models). The equilibrium of the system of equations is defined by a set of prices and quantities where:

- $\quad$ Firms make zero profits (i.e., zero extraordinary profits once all productive factors have been paid).

- All goods, services and factor markets (except for labour) clear (i.e., a standard assumption in this literature, in a medium-run view).

- Three sets of constraints hold, namely, (i) revenue equals expenditure for all agents, (ii) the labour market incorporates unemployment, and (iii) the macroeconomic closure of the model.

A brief description of the model is presented below; the whole list of equations can be seen in Appendix A. 
The production function for each sector is a nested CES-Leontief function on intermediate inputs and primary factors with constant returns to scale, unlike three sectors (i.e., Agriculture, Mining and Energy) for which natural resources is a specific factor, so that decreasing returns hold for these sectors. Firms set prices competitively, with free entry and exit of firms, and maximise profits subject to their technology given by the production functions. Demands for primary factors and intermediate inputs are obtained using the Shephard's lemma on cost functions. These intermediate demands are used in the equilibrium conditions.

On the final demand side, each country has a private representative household and a government sector. Since the GTAP9inGAMS model has one single representative agent for each country, we have used several data sources, such as National Accounts, the GTAP 9 Data Base (see Narayanan et al. [11]), United Nations [12] and World Health Organization [13] in order to separate this single agent into the private and public ones).

The representative private household is defined by a welfare function and a budget constraint. Specifically, demands of goods and services are derived from the maximisation of a Cobb-Douglas welfare function subject to a budget constraint that includes endogenous rents from factor endowments and exogenous savings. The other final consumer is the government who acts as purchaser of a Leontief composite of goods (i.e., public administration, defence, education, health and social services). This Leontief structure is allowed to change in order to incorporate a larger share of health services on total public expenditure for the 12 emerging countries included in the model. On the other hand, the government resources are the net revenues from net taxes on primary factors (labour, capital and natural resources), indirect taxes (taxes on intermediate inputs, taxes on goods and tariffs) and subsidies (on output and exports).

Each country acts as an open economy with potential exports and imports as regards the remaining countries. The levels of exports and imports are endogenous, and trade imbalances are allowed for each country, although there is trade balance at global level. Traded goods are differentiated according to their origin at two nested levels: (i) domestic and foreign; (ii) among different foreign countries. This framework follows Armington's [14] assumption, so intra-industry trade is allowed for all kinds of goods.

Regarding factor markets, the representative private household is the only owner of the (fixed endowments of) natural resources, capital and labour, all of them assumed to be immobile at international level. Natural resources are sector-specific to three sectors (i.e., Agriculture, Mining and Energy), unlike labour and capital, which are mobile across sectors. The demand side was described above. Factor rents adjust in order to clear domestic markets in the cases of natural resources and capital. In turn, in the case of labour, since unemployment is endogenous, the level of employment (i.e., the fixed labour endowment minus unemployment) is also endogenous. There is a constraint that links the unemployment rate and the real wage, i.e., the so-called wage equation (see Blanchflower and Oswald [15]):

$$
\frac{W}{P}=\left(\frac{u}{u 0}\right)^{\beta}
$$

where $W$ denotes the nominal wage, $P$ stands for the consumer price index, $u$ is the unemployment rate, $u 0$ is the unemployment rate at the benchmark, and $\beta<0$. As can be seen, when $\beta \rightarrow 0$ the wage equation approaches a downward-rigid real wage (note that, by convention, the real wage at the benchmark is equal to 1). Labour demand is affected by taxes on labour.

The latter is a particular feature of our model. Since the policy simulated is intended to increase output in health services (and decrease it in other sectors due to opportunity costs), labour demand will be affected. Hence, the above function clarifies the flexibility that we have incorporated into the model by allowing for a trade-off between the real wage and the unemployment rate. Recall that this feature is not common in most CGE models, which typically assume the existence of full employment. 
Finally, to close the model, a macroeconomic identity where investment equals total savings (i.e., the aggregate of private, public and foreign savings) is included. This aggregate total investment is separated into sectoral gross capital formation by means of a Leontief function, following Dervis et al. [16].

\section{Calibration and Data Sources}

Calibration uses the GTAP 9 Data Base (see Narayanan et al. [11]) for the year 2011, together with a set of exogenous parameters. Most of the data for the splitting of the government sector comes from GTAP (i.e., regional public savings have been estimated as the difference between tax revenue and public expenditure). The elasticities in the production functions are shown in Table 3, and come from Narayanan et al. [11]. The wage curve parameter $\beta$ (i.e., the elasticity of the real wage with respect to the unemployment rate) has been fixed at -0.1 , i.e., a standard value from the wage curve literature (e.g., Blanchflower and Oswald [17]).

Table 3. Elasticities of substitution.

\begin{tabular}{cccc}
\hline & Factors & Domestic Production-Imports & Intra-Imports \\
\hline Agriculture & 0.255 & 2499 & 4.866 \\
Mining & 0.200 & 0.900 & 1.800 \\
Energy & 0.500 & 5.165 & 13.146 \\
Industry & 1.240 & 3.297 & 6.971 \\
Construction & 1.400 & 1.900 & 3.800 \\
Government services & 1.260 & 1.900 & 3.800 \\
Other services & 1.408 & 1.909 & 3.803 \\
\hline
\end{tabular}

Source: GTAP 9 Data Base, Narayanan et al. [11].

The sector Government services has been split into two subsectors, i.e., health services and the rest of government services, except for Rest of the World, and using data from World Health Organization [13]. The share of the health expenditure on total general government expenditure for each country is shown in Table 4 . The table also shows the unemployment rates and the share of public gross capital formation on total gross capital formation at national level, with data taken from National Accounts, World Bank [18] and United Nations [12]. Finally, all figures in Table 4 refer to our benchmark year, i.e., 2011.

Table 4. Country variables.

\begin{tabular}{cccc}
\hline & $\begin{array}{c}\text { Government Health } \\
\text { Expenditure (\% of General } \\
\text { Government Expenditure) }\end{array}$ & $\begin{array}{c}\text { Unemployment } \\
\text { Rate (\%) }\end{array}$ & $\begin{array}{c}\text { Public Gross Capital } \\
\text { Formation (\% of Total GCF) }\end{array}$ \\
\hline Brazil & 9.2 & 6.69 & 14.2 \\
Chile & 14.0 & 7.34 & 9.4 \\
China & 8.6 & 4.34 & 10.9 \\
Colombia & 17.3 & 10.19 & 13.6 \\
India & 3.4 & 3.53 & 14.4 \\
Kazakhstan & 8.8 & 5.39 & 20.5 \\
Mexico & 10.6 & 5.19 & 11.9 \\
Morocco & 7.0 & 8.91 & 11.4 \\
Peru & 12.2 & 3.44 & 19.4 \\
Russia & 9.0 & 6.54 & 10.6 \\
South Africa & 13.2 & 24.65 & 17.7 \\
Tunisia & 12.4 & 18.33 & 23.1 \\
Rest of the World & - & 5.60 & 17.1 \\
\hline
\end{tabular}




\section{Simulation Results}

We have performed three different simulations. In all three, the level of health services is fixed up to $20 \%$ of total real government expenditure (i.e., a level comparable to that of the most advanced countries; see Table 1). The starting values for each country are shown in the first column of Table 4. Notice that, by using the spending on health services as a share of total government expenditure, rather than its share of GDP, it is possible to capture more precisely the commitment of the government to such policy (see Rudra [19]). This simulated target is reached simultaneously by all countries, except for Rest of the World that keeps its benchmark level. In all the simulations, it is assumed that the rest of government expenditure does not change; since the whole public expenditure (i.e., public health services plus the rest of government expenditure) is endogenous, this policy measure amounts to a fiscal expansion.

In addition, we have allowed for an increase in labour productivity, following the higher public expenditure in health services. World Health Organization [3] offers a wide overview of the literature that examines the effect of several health indicators (such as nutrition, life expectancy, disease and injury impact ... ) on labour productivity. For instance, Bloom et al. [20] found, for a panel of 104 countries, that, by raising labour productivity, each extra year of life expectancy led to a $4 \%$ increase in output. There are also some estimates of the link between health expenditure and improvement in some of the above health indicators; see, e.g., the results of Novignon et al. [21] for a panel of 44 African countries. However, since, as far as we know, there is no robust numerical evidence on the direct impact of health expenditure on labour productivity, we have opted for assuming a rather conservative, exogenous increase in labour productivity of 3\% in all the countries analysed. Notice that, following Torój [22], an alternative way to introduce a productivity improvement would be to model a "health stock" variable that could increase due to the greater health expenditure. Though valid for macroeconometric models, we think this approach is not suitable here given the theoretical and empirical basis of the production function nests in our multi-sectoral CGE model.

On the other hand, the increase in health spending in the first scenario results in a higher government deficit, which is simulated as endogenous. The other two scenarios, in turn, assume that taxes are raised endogenously in order to counterweigh the increase in government expenditure and so keeping the level of government deficit unchanged. Specifically, direct tax rates on labour and indirect tax rates are raised in the second and third scenarios, respectively.

The results of the three simulations on the main macroeconomic variables are shown in Table 5 as percentage changes from benchmark values, except for the unemployment rate and the ratio of government deficit to GDP, where changes are denoted as percentage points. The numeraire used is the consumer price index of Rest of the World. The variables selected are GDP, employment, unemployment rate, real wage rate, compensation of employees, gross operating surplus and ratio government deficit/GDP, for the economies of the 12 emerging countries and an additional region representing the economy of the rest of the world. Notice that GDP is measured at factor cost, so that it equals the sum of the compensation of employees and gross operating surplus. 
Table 5. Simulation results: Effect on macroeconomic variables (\% change from benchmark).

A. Government deficit endogenous.

\begin{tabular}{|c|c|c|c|c|c|c|c|c|c|c|c|c|c|}
\hline & Brazil & Chile & China & Colombia & India & Kazakhstan & Mexico & Morocco & Peru & Russia & South Africa & Tunisia & Rest of World \\
\hline GDP & 2.19 & 0.71 & 1.42 & 0.47 & 1.38 & 1.20 & 1.01 & 2.04 & -2.41 & 1.82 & 1.84 & 1.28 & -0.01 \\
\hline Employment & 0.80 & 0.03 & 0.23 & -0.16 & 0.14 & 0.23 & 0.11 & 0.55 & -0.21 & 0.58 & 0.87 & 0.67 & -0.01 \\
\hline Unemployment (p.p.) & -0.74 & -0.03 & -0.22 & 0.14 & -0.14 & -0.21 & -0.11 & -0.50 & 0.21 & -0.54 & -0.65 & -0.54 & 0.01 \\
\hline Real wage rate & 1.34 & -0.43 & 0.36 & -0.65 & 0.44 & -0.14 & 0.30 & 0.56 & -3.51 & 1.31 & 0.41 & 0.22 & -0.02 \\
\hline Compensation of employees & 2.15 & -0.40 & 0.59 & -0.81 & 0.58 & 0.09 & 0.42 & 1.12 & -3.72 & 1.90 & 1.28 & 0.89 & -0.03 \\
\hline Gross operating surplus & 2.45 & 1.63 & 2.21 & 1.31 & 1.97 & 2.05 & 1.34 & 3.20 & -1.26 & 2.02 & 2.44 & 1.65 & -0.01 \\
\hline Government deficit/GDP (p.p.) & 3.36 & 0.78 & 2.04 & 0.24 & 3.06 & 1.89 & 1.34 & 3.20 & 0.96 & 3.66 & 1.75 & 1.91 & 0.00 \\
\hline \multicolumn{14}{|c|}{ B. Increase in direct taxes on labour. } \\
\hline & Brazil & Chile & China & Colombia & India & Kazakhstan & Mexico & Morocco & Peru & Russia & South Africa & Tunisia & Rest of World \\
\hline GDP & -2.63 & -0.16 & -0.73 & 0.59 & 0.70 & -0.45 & -0.65 & -2.25 & 0.50 & -3.04 & -1.98 & -1.26 & 0.00 \\
\hline Employment & -2.86 & -0.81 & -1.20 & 0.06 & -0.19 & -0.93 & -1.46 & -2.53 & -0.24 & -4.36 & -3.76 & -2.47 & 0.00 \\
\hline Unemployment (p.p.) & 2.67 & 0.75 & 1.15 & -0.06 & 0.18 & 0.88 & 1.38 & 2.30 & 0.24 & 4.08 & 2.84 & 2.01 & 0.00 \\
\hline Real wage rate & -3.00 & -1.31 & -2.05 & -0.62 & -0.79 & -1.82 & -2.29 & -2.23 & -0.81 & -4.22 & -0.84 & -0.96 & 0.00 \\
\hline Compensation of employees & -5.77 & -2.12 & -3.22 & -0.56 & -0.98 & -2.73 & -3.71 & -4.71 & -1.05 & -8.40 & -4.57 & -3.40 & 0.00 \\
\hline Gross operating surplus & 1.00 & 1.46 & 2.38 & 1.33 & 1.87 & 2.03 & 0.91 & 2.03 & 2.40 & 0.58 & 0.71 & 0.75 & 0.00 \\
\hline Government deficit/GDP (p.p.) & -0.08 & 0.01 & 0.00 & -0.04 & 0.01 & -0.01 & -0.01 & 0.29 & 0.03 & -0.39 & 0.16 & -0.06 & 0.00 \\
\hline \multicolumn{14}{|c|}{ C. Increase in indirect taxes. } \\
\hline & Brazil & Chile & China & Colombia & India & Kazakhstan & Mexico & Morocco & Peru & Russia & South Africa & Tunisia & Rest of World \\
\hline GDP & 1.14 & 0.55 & 0.89 & 0.37 & 0.71 & 0.97 & 0.92 & 1.43 & 0.98 & -0.64 & 0.12 & 0.11 & -0.01 \\
\hline Employment & -0.88 & -0.44 & -0.54 & -0.38 & -0.29 & -0.77 & -0.57 & -0.05 & -0.18 & -1.32 & -1.41 & -0.70 & -0.01 \\
\hline Unemployment (p.p.) & 0.82 & 0.41 & 0.52 & 0.34 & 0.28 & 0.73 & 0.54 & 0.05 & 0.18 & 1.23 & 1.06 & 0.57 & 0.01 \\
\hline Real wage rate & 1.77 & -0.15 & 0.62 & -0.59 & 0.47 & 0.82 & 0.73 & 0.62 & 0.06 & 0.89 & 0.83 & 0.51 & -0.02 \\
\hline Compensation of employees & 0.88 & -0.59 & 0.07 & -0.97 & 0.17 & 0.04 & 0.15 & 0.56 & -0.12 & -0.44 & -0.59 & -0.19 & -0.03 \\
\hline Gross operating surplus & 1.64 & 1.49 & 1.78 & 1.27 & 1.41 & 2.13 & 1.33 & 2.59 & 2.17 & -0.13 & 0.86 & 0.42 & -0.01 \\
\hline Government deficit/GDP (p.p.) & -0.03 & 0.02 & 0.00 & -0.02 & -0.01 & 0.07 & 0.01 & 0.26 & 0.04 & -0.20 & 0.06 & 0.02 & 0.00 \\
\hline
\end{tabular}


The results of the first simulation, i.e., when the government deficit is endogenous, are shown in panel A of Table 5. The increase in the share of health services in total public expenditure has an expansionary effect on GDP in all countries, ranging between $2.19 \%$ for Brazil and $0.47 \%$ for Colombia; the only exception is Peru, where GDP would decrease by $2.41 \%$. This increase in GDP is accompanied by higher employment and a lower unemployment rate, except for Colombia and Peru. There is a positive effect on wages and a rise in the compensation of employees in most cases (with the exceptions of Chile, Colombia and Peru), which, coupled with a greater increase in the gross operating surplus (except for Peru), result in a generalised redistributive effect detrimental to workers. Not surprisingly, the ratio of government deficit to GDP rises in all countries, with the increase ranging between 3.66 points for Russia and 0.24 points for Colombia.

Since the increase in government deficit is sizeable for some countries, in the next two simulations we allow for taxes to rise endogenously in order to offset the increase in public health services expenditure, keeping the government deficit unchanged. When direct tax rates on labour are increased, as shown in panel B of Table 5, the former expansionary effect on GDP becomes contractionary in most cases; in particular, GDP falls by $3.04 \%$ and $2.63 \%$ in Russia and Brazil, respectively (i.e., those countries with the highest direct taxes on labour at the benchmark). On the contrary, Colombia, India and Peru (i.e., the countries with the lowest direct taxes on labour at the benchmark) show modest increases in GDP. Following the increase in labour taxes a negative effect on employment appears and the unemployment rate rises (except for the case of Colombia, even though the effect is close to zero), and there is a fall in wages that tends to offset the increase in labour taxes. Since there is a fall in the compensation of employees and a rise in the gross operating surplus, the redistributive effect detrimental to workers is now even stronger. In addition, there is no clear pattern for the ratio of government deficit to GDP, although changes are generally small.

On the other hand, when the increase in the share of health services is accompanied by a rise in indirect taxes, the results in panel C of Table 5 show a modest increase in GDP for all countries with the only exception of Russia, where GDP falls by $0.64 \%$. As before, the tax increase leads to lower employment, with an increase in the unemployment rate, but now there is a rise in wages (except for Chile and Colombia). The different evolutions across countries of the compensation of employees and gross operating surplus lead again to a redistributive effect detrimental to workers in all countries. The effects on the ratio of government deficit to GDP are very similar to those in the previous scenario, although quantitatively smaller in most cases.

Finally, the effects on the rest of the world, transmitted through trade flows, are mostly negligible, as shown in Table 5 .

Next, we will present the effects on some sectoral variables, which can give us some additional information that helps to explain the previous macroeconomic results. In particular, we will consider the variables employment and output; the effects of the simulations above on these variables are shown in Tables 6 and 7, respectively. 
Table 6. Simulation results: Effect on sectoral output (\% change from benchmark).

A. Government deficit endogenous.

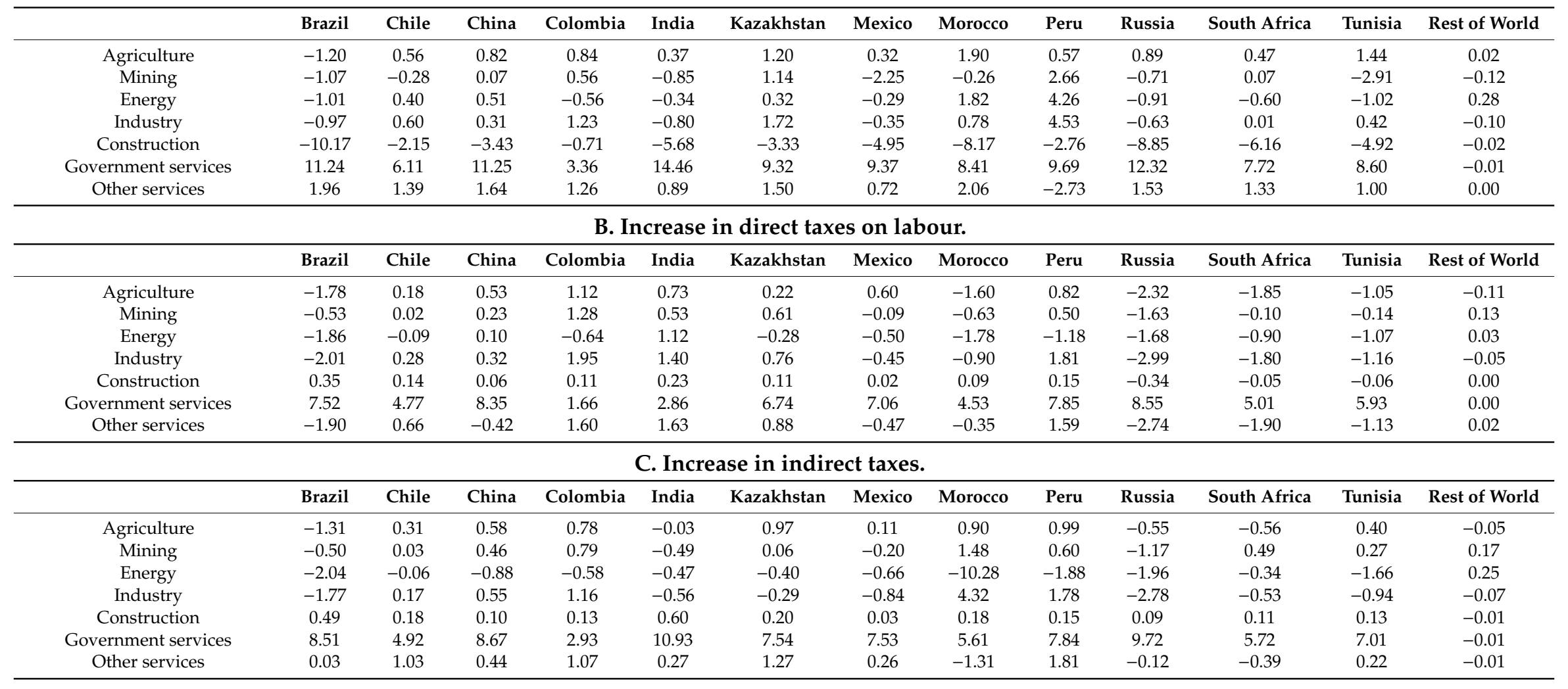


Table 7. Simulation results: Effect on sectoral employment (\% change from benchmark).

A. Government deficit endogenous.

\begin{tabular}{|c|c|c|c|c|c|c|c|c|c|c|c|c|c|}
\hline & Brazil & Chile & China & Colombia & India & Kazakhstan & Mexico & Morocco & Peru & Russia & South Africa & Tunisia & Rest of World \\
\hline Agriculture & -4.20 & -2.02 & -1.78 & -1.68 & -2.24 & -1.22 & -2.47 & -0.65 & -2.08 & -1.76 & -2.14 & -1.24 & 0.02 \\
\hline Mining & -4.06 & -3.00 & -2.73 & -2.10 & -3.73 & -1.49 & -5.38 & -3.03 & 0.37 & -3.72 & -2.77 & -6.22 & -0.14 \\
\hline Energy & -3.78 & -1.74 & -1.81 & -2.91 & -2.88 & -1.75 & -3.00 & -0.30 & 3.34 & -4.08 & -3.26 & -3.63 & 0.37 \\
\hline Industry & -3.39 & -0.75 & -1.62 & -0.36 & -2.84 & -0.12 & -2.48 & -0.98 & 2.61 & -3.22 & -1.63 & -1.57 & -0.09 \\
\hline Construction & -12.31 & -4.15 & -5.66 & -1.82 & -8.18 & -4.98 & -7.03 & -9.80 & -5.20 & -11.11 & -7.92 & -7.24 & -0.01 \\
\hline Government services & 8.07 & 3.55 & 8.24 & 0.76 & 11.36 & 6.67 & 6.38 & 5.93 & 6.40 & 9.11 & 4.94 & 5.51 & -0.01 \\
\hline Other services & -0.35 & -0.06 & -0.01 & -0.04 & -0.91 & -0.26 & -1.23 & 0.53 & -4.05 & -0.83 & -0.05 & -0.78 & 0.01 \\
\hline \multicolumn{14}{|c|}{ B. Increase in direct taxes on labour. } \\
\hline & Brazil & Chile & China & Colombia & India & Kazakhstan & Mexico & Morocco & Peru & Russia & South Africa & Tunisia & Rest of World \\
\hline Agriculture & -5.37 & -2.62 & -2.06 & -1.23 & -1.52 & -2.63 & -1.89 & -4.77 & -1.70 & -6.29 & -5.46 & -4.35 & -0.15 \\
\hline Mining & -3.89 & -2.77 & -2.49 & -1.23 & -2.06 & -2.19 & -3.14 & -3.70 & -2.21 & -5.35 & -3.29 & -3.39 & 0.15 \\
\hline Energy & -5.95 & -2.54 & -1.90 & -2.75 & -0.82 & -3.10 & -3.78 & -4.79 & -3.60 & -7.00 & -5.14 & -5.10 & 0.05 \\
\hline Industry & -5.96 & -1.66 & -0.95 & 0.80 & 0.08 & -1.57 & -3.69 & -3.96 & -0.18 & -8.35 & -6.27 & -5.48 & -0.05 \\
\hline Construction & -3.80 & -2.25 & -1.73 & -0.41 & -2.16 & -2.14 & -3.22 & -3.01 & -2.42 & -6.60 & -4.34 & -3.81 & 0.00 \\
\hline Government services & 3.99 & 2.02 & 5.63 & -0.74 & 0.31 & 3.90 & 3.76 & 1.34 & 4.61 & 4.31 & 1.35 & 2.53 & 0.00 \\
\hline Other services & -6.17 & -1.36 & -5.37 & 0.85 & 0.79 & -1.41 & -3.77 & -3.45 & 0.04 & -9.80 & -6.67 & -5.74 & 0.03 \\
\hline \multicolumn{14}{|c|}{ C. Increase in indirect taxes. } \\
\hline & Brazil & Chile & China & Colombia & India & Kazakhstan & Mexico & Morocco & Peru & Russia & South Africa & Tunisia & Rest of World \\
\hline Agriculture & -4.53 & -2.42 & -2.15 & -1.76 & -2.97 & -1.58 & -2.79 & -1.82 & -1.44 & -3.79 & -3.63 & -2.57 & -0.07 \\
\hline Mining & -3.58 & -2.71 & -2.34 & -1.88 & -3.41 & -2.84 & -3.14 & -1.19 & -2.09 & -4.44 & -2.45 & -2.69 & 0.20 \\
\hline Energy & -5.45 & -2.38 & -3.86 & -2.98 & -3.22 & -3.28 & -3.65 & -12.35 & -4.47 & -6.20 & -3.52 & -5.04 & 0.33 \\
\hline Industry & -4.78 & -1.52 & -1.79 & -0.51 & -2.96 & -2.58 & -3.32 & 2.17 & -0.21 & -6.25 & -3.49 & -3.98 & -0.06 \\
\hline Construction & -2.60 & -2.07 & -2.47 & -1.09 & -2.20 & -2.03 & -2.51 & -1.91 & -2.41 & -3.67 & -2.88 & -2.91 & 0.00 \\
\hline Government services & 5.24 & 2.26 & 5.62 & 0.32 & 7.80 & 4.69 & 4.47 & 3.01 & 4.61 & 6.20 & 2.56 & 3.79 & -0.01 \\
\hline Other services & -3.05 & -0.75 & -1.72 & -0.32 & -1.99 & -1.00 & -2.14 & -3.16 & 0.26 & -4.09 & -3.36 & -2.87 & 0.00 \\
\hline
\end{tabular}


The general pattern is somewhat different for both variables, as can be seen in the tables. The simulated policies lead to an increase in output in the public health services included in Government services, which takes productive factors up from other sectors. Since input use is reduced in the rest of sectors, their employment contracts accordingly. However, given our assumption of an increase in labour productivity following the rise in public health expenditure, this fall in employment coexists with an asymmetric output effect across sectors, with some sectors in some countries increasing their output, although generally in a small amount. Those countries showing more sectors with positive results in terms of output are Chile, China, Colombia, Kazakhstan and Peru. Notice that, in the first simulation (i.e., when the government deficit is endogenous), the sector that is the most negatively affected in all countries is Construction. Since an increase in government deficit means a fall in savings (via public savings), macroeconomic equilibrium requires a corresponding fall in investment, so reducing the levels of activity in the Construction sector, which is the main driving force of gross capital formation. Note also the strong asymmetrical effect in Morocco in the third simulation (i.e., when indirect taxes are increased), with a big fall in activity in Energy and, to a lower extent, Other services, due to the relevance of some sectoral subsidies in those sectors.

With regard to the differences in results across countries, it is rather difficult to establish a general pattern, since they depend on many factors in this general equilibrium framework: from the starting point of the level of health spending, or the weight of the whole government expenditure on GDP, to the tax structure and the level of direct and indirect taxes, or the unemployment rate at the benchmark. Hence, the result of the simulations should be the element that clarifies all the ambiguities in the impacts that might be expected a priori. In this sense, CGE becomes a useful tool for solving these multi-sector, multi-country models. As an example, there are some countries, as can be seen in Table 1, that start from a public provision of health services close to $20 \%$ (such as Colombia or Chile) and others very far from those levels (such as India, Morocco or Kazakhstan), so that, if the latter must rise taxes, they should be relatively more affected by the simulated policy. Also, the unemployment rate can act as a buffer dampening the effects of higher direct taxes on labour; however, as can be seen in Table 4, it is very high in some countries (such as South Africa and Tunisia) and rather small in others (such as Peru, India and China).

Finally, we have performed a sensitivity analysis of the results. For all scenarios, four exogenous parameters have been doubled and halved, i.e., the elasticity of substitution between labour and capital $\left(\sigma_{i}^{V A}\right)$, the Armington elasticity of substitution between domestic and imported goods $\left(\sigma_{i}^{d}\right)$, the elasticity of substitution among imported varieties $\left(\sigma_{i}^{m}\right)$, and the elasticity of the real wage with respect to the unemployment rate $(\beta)$. The results for GDP are shown in Table 8; the results for the rest of variables are available from the authors upon request. In general, the results for all the countries and scenarios are rather robust, especially for larger countries. 
Table 8. Sensitivity analysis: Effects on GDP (\% change from base simulation).

A. Government deficit endogenous.

\begin{tabular}{|c|c|c|c|c|c|c|c|c|c|c|c|c|c|}
\hline & Brazil & Chile & China & Colombia & India & Kazakhstan & Mexico & Morocco & Peru & Russia & South Africa & Tunisia & Rest of World \\
\hline $\begin{array}{c}\text { Base simulation } \\
\sigma_{i}^{V A}=[0.200-1.408]\end{array}$ & 2.19 & 0.71 & 1.42 & 0.47 & 1.38 & 1.20 & 1.01 & 2.04 & -2.41 & 1.82 & 1.84 & 1.28 & -0.01 \\
\hline$\sigma_{i}^{\prime} V A=2 * \sigma_{i}^{V A}$ & 2.21 & 0.78 & 1.55 & 0.74 & 1.82 & 1.08 & 0.99 & 1.96 & 1.23 & 1.27 & 1.95 & 1.80 & 0.00 \\
\hline $\begin{array}{c}\sigma_{\dot{i}}^{i} V A=0.5 * \sigma_{i}^{V A} \\
\sigma_{i}^{\mathrm{d}}=[0.900-5.165]\end{array}$ & 2.19 & 0.48 & 1.22 & 0.34 & 1.51 & 1.25 & 0.93 & 1.50 & 1.03 & 1.39 & 1.20 & 1.08 & -0.01 \\
\hline$\sigma_{i}^{\prime d}=2 * \sigma_{i}^{\mathrm{d}}$ & 2.29 & 2.13 & 1.43 & 0.54 & 0.83 & -2.04 & 1.64 & -0.73 & 2.41 & 1.79 & 1.05 & 0.09 & -0.01 \\
\hline $\begin{array}{c}\sigma_{i}^{\prime} \mathrm{d}^{l}=0.5 * \sigma_{i}^{\mathrm{d}} \\
\sigma_{i}^{\mathrm{m}} \stackrel{1}{=}[1.800-13.146]\end{array}$ & 2.28 & 0.49 & 1.42 & 0.45 & 1.78 & 1.76 & 0.99 & 1.48 & 1.04 & 1.33 & 1.66 & 0.71 & -0.01 \\
\hline$\sigma_{i}^{\prime \mathrm{m}}=2 * \sigma_{i}^{\mathrm{m}}$ & 2.09 & 0.83 & 1.48 & 0.62 & 1.50 & 1.47 & 0.95 & 1.93 & 1.41 & 1.30 & 1.51 & 1.34 & -0.01 \\
\hline 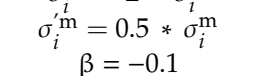 & 2.59 & -0.40 & 1.34 & 0.45 & 1.86 & 1.43 & 0.94 & 1.41 & 1.11 & 1.45 & 2.01 & 1.38 & -0.01 \\
\hline$\beta^{\prime}=2 * \beta$ & 2.12 & 0.77 & 1.38 & 0.51 & 1.63 & 1.41 & 1.01 & 1.60 & 1.29 & 1.31 & 1.44 & 1.19 & -0.01 \\
\hline$\beta^{\prime}=0.5 * \beta$ & 2.21 & -0.44 & 1.48 & 0.37 & 1.94 & 3.20 & 0.63 & 1.00 & 0.03 & 1.12 & 1.89 & 1.38 & -0.01 \\
\hline \multicolumn{14}{|c|}{ B. Increase in direct taxes on labour. } \\
\hline & Brazil & Chile & China & Colombia & India & Kazakhstan & Mexico & Morocco & Peru & Russia & South Africa & Tunisia & Rest of World \\
\hline $\begin{array}{c}\text { Base simulation } \\
\sigma_{i}^{V A}=[0.200-1.408]\end{array}$ & -2.63 & -0.16 & -0.73 & 0.59 & 0.70 & -0.45 & -0.65 & -2.25 & 0.50 & -3.04 & -1.98 & -1.26 & 0.00 \\
\hline$\sigma_{i}^{\prime} V A=2 * \sigma_{i}^{V A}$ & -3.19 & -0.01 & -0.71 & 0.88 & 0.89 & -0.35 & -0.68 & -2.31 & 0.62 & -4.78 & -2.78 & -1.78 & -0.01 \\
\hline $\begin{array}{c}\sigma_{i}^{V} V A=0.5 * \sigma_{i}^{V A} \\
\sigma_{i}^{d}=[0.900-5.165]\end{array}$ & -2.15 & -0.35 & -0.79 & 0.33 & 0.43 & -0.59 & -0.62 & -2.20 & 0.32 & -2.16 & -1.49 & -0.96 & 0.00 \\
\hline$\sigma_{i}^{\prime d}=2 * \sigma_{i}^{\mathrm{d}}$ & -2.73 & -0.14 & -0.73 & 0.75 & 0.78 & -0.40 & -0.66 & -2.31 & 0.56 & -3.05 & -2.06 & -1.29 & 0.00 \\
\hline $\begin{array}{c}\sigma_{i}^{\prime} \mathrm{d}^{2}=0.5 * \sigma_{i}^{\mathrm{d}} \\
\sigma_{i}^{\mathrm{m}}=[1.800-13.146]\end{array}$ & -2.55 & -0.17 & -0.74 & 0.47 & 0.64 & -0.49 & -0.65 & -2.21 & 0.45 & -3.02 & -1.90 & -1.24 & -0.01 \\
\hline$\sigma_{i}^{\prime m}=2 * \sigma_{i}^{\mathrm{m}}$ & -2.78 & -0.10 & -0.72 & 0.76 & 0.88 & -0.39 & -0.69 & -2.35 & 0.63 & -3.11 & -2.16 & -1.39 & 0.00 \\
\hline $\begin{array}{c}\sigma_{i}^{l}=0.5 * \sigma_{i}^{\mathrm{m}} \\
\beta=-0.1\end{array}$ & -2.46 & -0.25 & -0.74 & 0.48 & 0.46 & -0.48 & -0.60 & -2.13 & 0.34 & -2.90 & -1.73 & -1.07 & -0.01 \\
\hline$\beta^{\prime}=2 * \beta$ & -1.79 & -0.01 & -0.47 & 0.60 & 0.72 & -0.21 & -0.45 & -1.76 & 0.56 & -2.25 & -1.43 & -0.92 & 0.00 \\
\hline$\beta^{\prime}=0.5 * \beta$ & -4.57 & -0.40 & -1.19 & 0.57 & 0.67 & -0.87 & -0.98 & -2.89 & 0.39 & -4.36 & -2.50 & -1.61 & 0.00 \\
\hline
\end{tabular}


Table 8. Cont.

C. Increase in indirect taxes.

\begin{tabular}{|c|c|c|c|c|c|c|c|c|c|c|c|c|c|}
\hline & Brazil & Chile & China & Colombia & India & Kazakhstan & Mexico & Morocco & Peru & Russia & South Africa & Tunisia & Rest of World \\
\hline $\begin{array}{c}\text { Base simulation } \\
\sigma_{i}^{V A}=[0.200-1.408]\end{array}$ & 1.14 & 0.55 & 0.89 & 0.37 & 0.71 & 0.97 & 0.92 & 1.43 & 0.98 & -0.64 & 0.12 & 0.11 & -0.01 \\
\hline$\sigma_{i}^{\prime} V A=2 * \sigma_{i}^{V A}$ & 1.04 & 0.71 & 0.97 & 0.55 & 0.76 & 1.01 & 0.94 & 1.57 & 1.08 & -1.13 & 0.11 & 0.05 & -0.01 \\
\hline $\begin{array}{c}\sigma_{i}^{\prime V A}=0.5 * \sigma_{i}^{V A} \\
\sigma_{i}^{\mathrm{d}}=[0.900-5.165]\end{array}$ & 1.25 & 0.35 & 0.79 & 0.19 & 0.64 & 0.89 & 0.89 & 1.24 & 0.81 & -0.21 & 0.13 & 0.14 & -0.01 \\
\hline$\sigma_{i}^{\prime \mathrm{d}}=2 * \sigma_{i}^{\mathrm{d}}$ & 1.09 & 0.55 & 0.97 & 0.47 & 0.78 & 0.91 & 0.98 & 2.02 & 1.06 & -0.67 & -0.08 & 0.39 & -0.02 \\
\hline 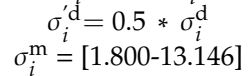 & 1.19 & 0.56 & 0.84 & 0.29 & 0.64 & 1.02 & 0.87 & 0.67 & 0.93 & -0.62 & 0.27 & -0.08 & -0.01 \\
\hline$\sigma_{i}^{\prime \mathrm{m}}=2 * \sigma_{i}^{\mathrm{m}}$ & 1.05 & 0.61 & 0.90 & 0.49 & 0.53 & 1.00 & 0.81 & 0.75 & 1.09 & -0.71 & 0.24 & -0.06 & -0.01 \\
\hline $\begin{array}{c}\sigma_{i}^{\prime l}=0.5 * \sigma_{i}^{\mathrm{m}} \\
\beta=-0.1\end{array}$ & 1.26 & 0.46 & 0.88 & 0.28 & 0.95 & 0.95 & 1.09 & 2.29 & 0.82 & -0.51 & -0.04 & 0.59 & -0.02 \\
\hline$\beta^{\prime}=2 * \beta$ & 1.28 & 0.61 & 0.99 & 0.40 & 0.75 & 1.12 & 0.97 & 1.44 & 1.02 & -0.47 & 0.26 & 0.17 & -0.01 \\
\hline$\beta^{\prime}=0.5 * \beta$ & 0.90 & 0.47 & 0.74 & 0.32 & 0.65 & 0.73 & 0.85 & 1.42 & 0.91 & -0.87 & 0.00 & 0.05 & -0.02 \\
\hline
\end{tabular}




\section{Conclusions}

The United Nations General Assembly set in 2015 the SDGs, i.e., a collection of 17 global goals designed to achieve a more sustainable future for the planet. Within these 17 SDGs, number 3 relates to improved health conditions, which, by enhancing the well-being of population, should result in a more sustainable development of the planet as a whole. Since, on the other hand, emerging countries show a lower government involvement in the provision of health services, a higher public provision of health services should result in a more sustainable growth in those countries.

In this paper, we have tried to quantify the effects of an increase in the public provision of health services in a set of emerging economies, using a CGE model, which allows obtaining the consequences of changes in a particular variable on the whole economy, as well as the specific effects across the different productive sectors. In particular, the model we used is an extension of the GTAP model on several grounds: (i) the representative agent is split between public and private agents; (ii) the savings and expenditure of the government are endogenous; (iii) unemployment is included through a wage curve approach; and (iv) the trade balance is endogenous at national level. The analysis has been applied to 12 emerging countries (i.e., Brazil, Chile, China, Colombia, India, Kazakhstan, Mexico, Morocco, Peru, Russia, South Africa and Tunisia), selected on the basis of data availability regarding national public sectors within a unified methodology across countries, where these 12 economies represent $45 \%$ of world population in 2018.

We have simulated an increase in the level of the real government expenditure devoted to health services, which is fixed up to a $20 \%$ of total government expenditure (i.e., a level comparable to that of the most advanced countries), with this target being reached simultaneously by all the countries analysed. In addition, we have allowed for an increase of $3 \%$ in labour productivity, following the higher public expenditure in health services. From here, this basic simulation has been performed in three different scenarios: in the first scenario, the increase in health spending results in a higher government deficit, which is simulated as endogenous, while in the other two scenarios taxes are raised endogenously in order to offset the increase in government expenditure and so keeping the level of government deficit unchanged; specifically, we consider, alternatively, increases in direct tax rates on labour and in indirect tax rates, in each of the other two scenarios.

When the government deficit was left as endogenous (scenario 1), we found expansionary effects in terms of GDP and employment for all the economies under analysis, together with a redistributive effect detrimental to workers, and an increase in the ratio of government deficit to GDP, ranging between 3.66 points for Russia and 0.24 points for Colombia. If direct tax rates on labour are increased to offset the latter result (scenario 2), the effects on GDP and employment become contractionary in most cases, and the redistributive effect against labour turns to be even stronger, with no clear pattern for the ratio of government deficit to GDP, even though changes are generally small. In turn, if indirect tax rates are those to be increased (scenario 3), now a modest increase in GDP appears for all countries with the only exception of Russia, where GDP falls. As before, there is a redistributive effect detrimental to workers, and the effects on the ratio of government deficit to GDP are very similar to those in the previous scenario, although quantitatively smaller in most cases. Finally, regarding the sectoral results, both employment and output increased in Government services and employment decreased in the rest of the sectors. However, given our assumption of an increase in labour productivity following the rise in public health expenditure, this fall in employment coexists with an asymmetric output effect across sectors, with some sectors in some countries increasing their output, although generally in a small amount. As an additional point, notice that, in general terms, those countries that are smaller in economic terms (e.g., Tunisia, Morocco, Kazakhstan, Peru) may be more affected in the simulations due to changes in trade flows since they are usually more open.

Summarising, and leaving aside the beneficial effects in themselves of a greater public involvement in the provision of health services, the results of this paper suggest that such a policy would result in expansionary effects in the economies concerned, coupled with an increase in the ratio of government deficit to GDP, which could be sizable for some countries. As in any other exercise like this, the results 
should be qualified given the limitations of these kinds of models. For instance, in spite of the detailed representation of international trade flows in CGE models, the monetary side of the economies is modelled in a very simplified way (in particular, international monetary capital flows are not included); or the short- to medium-run nature of the results. In any case, despite the heterogeneity across countries of direct tax rates on labour, an increase in those rates in order to fully offset the higher government deficit would turn the expansionary effects into contractionary in most cases. Then, according to our results, if the government wants to offset totally or partially its eventually higher deficit, it would be more advisable to do it with higher indirect taxes. In any case, some caveats are in order, given the simplified tax structure utilised, constrained by the need to have a common framework for all countries, and the short- to medium-run nature of CGE modelling. More generally, and provided that a greater public involvement in the provision of health services is deemed as something beneficial, countries should care about having proper means to finance government deficits. Also, in a medium-term perspective, it should be crucial to implement some supporting measures for the remaining sectors of the economy, which would contract following the expansion in the government sector.

Author Contributions: A.G.G.-P. carried out the design and estimation of the general equilibrium model. O.B.-R. contributed to the general design of the experiment and did the policy implications. Both authors were involved in writing the paper. Both authors have read and agreed to the published version of the manuscript. All authors have read and agree to the published version of the manuscript.

Funding: This research was funded by the Spanish Ministry of Economy, Industry and Competitiveness, through the projects ECO2016-78422-R and ECO2017-86054-C3-2-R, as well as from the University of Castilla-La Mancha through the project 2020-GRIN-29041, co-financed by the European Union via the European Regional Development Fund.

Acknowledgments: We acknowledge the comments of four anonymous referees.

Conflicts of Interest: The authors declare no conflict of interest.

\section{Appendix A}

As a general rule, the notation in the model is as follows: endogenous variables are denoted by capital letters, exogenous variables by capital letters with a bar, and parameters by small Latin and Greek letters. There are seven $(i, j=1, \ldots, 7)$ production sectors and each sector produces one good, except public services which can produce two types of goods: health services and other public services. The world economy is divided into 13 countries $(r, s=1, \ldots, 13)$. There are three productive factors ( $p f=$ labour, capital and specific; $F=$ labour, capital; $S=$ specific). All endogenous variables, and the exogenous variables and parameters, are listed in Tables A1 and A2 below. The description of the model is as follows.

\section{A.1. Production}

Technology presents constant returns to scale and firms apply a competitive pricing rule. For three sectors (Agriculture, Mining and Energy), natural resources is a fixed specific factor, so decreasing returns to scale are present. The nested production function of good $i$ in country $r$ is:

$$
Y_{i r}=\min \left(I I_{r}^{i}, V A_{r}^{i}\right)
$$

where:

$$
\begin{gathered}
V A_{r}^{i}=\left(\sum_{f} \theta_{i r}^{f}\left(Q_{i r}^{p f}\right)^{1-\sigma_{i}^{V A}}\right)^{\frac{1}{1-\sigma_{i}^{V A}}} \\
I I_{r}^{i}=\min \left(I I_{i 1 r}, \ldots, I I_{i 7 r}\right) \\
I I_{i j r}=\left(\theta_{i j r}^{d}\left(I I_{i j r}^{Y}\right)^{1-\sigma_{i}^{d}}+\left(1-\theta_{i j r}^{d}\right)\left(I I_{i j r}^{m}\right)^{1-\sigma_{i}^{d}}\right)^{\frac{1}{1-\sigma_{i}^{d}}}
\end{gathered}
$$


Since the top nest is a Leontief function, the zero-profit condition for sector $i$ in country $r$ is:

$$
\text { PROFIT }_{i r}^{Y}=P_{i r}^{Y}\left(1-t_{i r}^{O}\right)-\theta_{f} P_{i r}^{f}-\sum_{j=1}^{7} \theta_{j} P_{j r}^{i}=0
$$

where, according to the nested structure, the unit cost of the value-added composite produced by sector $i$ in country $r$ is a CES function:

$$
\begin{gathered}
P_{i r}^{f}=\left(\sum_{f} \theta_{i r}^{f}\left(P_{i r}^{p f}\right)^{1-\sigma_{i}^{V A}}\right)^{\frac{1}{1-\sigma_{i}^{V A}}} \\
P_{i r}^{p f}=\left\{\begin{array}{l}
P_{r}^{F}\left(1+t_{i r}^{F}\right) \\
P_{r}^{S}\left(1+t_{i r}^{S}\right.
\end{array}\right)
\end{gathered}
$$

where $F$ and $S$ denote labour and capital, and the specific factor, respectively.

The intermediate input price in PROFIT $T_{i r}^{Y}$ is an aggregate of national and imported intermediate input prices:

$$
P_{j r}^{i}=\left(\theta_{i j r}^{d}\left(1+t_{i j r}^{f d}\right)^{1-\sigma_{i}^{d}}\left(P_{j r}^{Y}\right)^{1-\sigma_{i}^{d}}+\left(1-\theta_{i j r}^{d}\right)\left(1+t_{i j r}^{f m}\right)^{1-\sigma_{i}^{d}}\left(P_{j r}^{m}\right)^{1-\sigma_{i}^{d}}\right)^{\frac{1}{1-\sigma_{i}^{d}}}
$$

These zero-profit conditions are used to derive the demand functions, by applying Shephard's lemma on cost functions.

Next, we introduce the corresponding market clearing equations, with demands in the left-hand side and supplies in the right-hand side. The factor demands $Q_{i r}^{p f}$ for capital, labour and the specific factor are represented in the left-hand side and they are, respectively:

$$
\begin{aligned}
& \sum_{i=1}^{7}\left(Y_{i r}\left(\frac{\partial P R O F I T_{i r}^{Y}}{\partial P_{r}^{\text {labour }}}\right)\right)=\overline{\text { EVOM }_{r}^{\text {labour }}}\left(1-U_{r}\right) \\
& \sum_{i=1}^{7}\left(Y_{i r}\left(\frac{\partial \text { PROFIT }_{i r}^{Y}}{\partial P_{r}^{\text {capital }}}\right)\right)=\overline{\operatorname{EVOM}_{r}^{\text {capital }}} \\
& \sum_{i=A G R I, M I N, E N E}\left(Y_{i r}\left(\frac{\partial P R O F I T_{i r}^{Y}}{\partial P_{r}^{S}}\right)\right)=\overline{E^{\prime} V M_{r}^{S}}
\end{aligned}
$$

The market equilibrium conditions for domestic and imported intermediate inputs are:

$$
\begin{aligned}
& Y_{i r}\left(\frac{\partial P R O F I T_{i r}^{Y}}{\partial P_{j r}^{Y}}\right)=I I_{i j r}^{Y} \\
& Y_{i r}\left(\frac{\partial P R O F I T_{i r}^{Y}}{\partial P_{j r}^{m}}\right)=I I_{i j r}^{m}
\end{aligned}
$$

Finally, the goods market equilibrium conditions are:

$$
C_{i r}^{C}+G_{i r}^{G}+I_{i r}^{I}+\sum_{j=1}^{7} I I_{i j r}^{Y}+\sum_{\substack{s=1 \\ s \neq r}}^{13} E X P_{i r s}-I M P_{i r}=Y_{i r}
$$


where:

$$
\begin{gathered}
C_{i r}^{C}=C_{i r}^{C d}+C_{i r}^{C m} \\
G_{i r}^{G}=G_{i r}^{G d}+G_{i r}^{G m} \\
I_{i r}^{I}=I_{i r}^{I d}+I_{i r}^{I m} \\
I M P_{i r}=C_{i r}^{C m}+G_{i r}^{G m}+I_{i r}^{I m}+\sum_{j=1}^{7} I I_{i j r}^{m} .
\end{gathered}
$$

\section{A.2. Consumption}

The final demand functions are derived from the maximization of the representative consumer's nested welfare function (or the equivalent dual problem, the minimization of the expenditure function $P C_{r} C_{r}^{p r i v}$ ). The welfare functions are:

$$
C_{r}^{p r i v}=\prod_{i=1}^{7}\left(C_{i r}^{C}\right)^{\theta_{i r}^{C}}
$$

where:

$$
C_{i r}^{C}=\left(\theta_{i r}^{C}\left(C_{i r}^{C d}\right)^{1-\sigma_{i}^{d}}+\left(1-\theta_{i r}^{C}\right)\left(C_{i r}^{C m}\right)^{1-\sigma_{i}^{d}}\right)^{\frac{1}{1-\sigma_{i}^{d}}}
$$

subject to the budget constraints:

$$
\begin{gathered}
I N C O M E_{r}^{\text {priv }}=P_{r}^{\text {labour }}\left(\overline{E V O M_{r}^{\text {labour }}}\right)\left(1-U_{r}\right)+P_{r}^{\text {capital }}\left(\overline{\operatorname{EVOM}_{r}^{\text {capital }}}\right)+P_{r}^{s}\left(\overline{E V O M_{r}^{S}}\right) \\
I N C O M E_{r}^{\text {priv }}=P R I V S A V_{r}+P C_{r} C_{r}^{\text {priv }}
\end{gathered}
$$

where:

$$
\begin{gathered}
\text { PRIVSAV } V_{r}=P I_{r} \overline{C_{r}^{\text {privsav }}} \\
\operatorname{PC}_{r} C_{r}^{\text {priv }}=\sum_{i=1}^{7} P_{i r}^{C} C_{i r}^{C} \\
P_{i r}^{C}=\left(\theta_{i r}^{C}\left(1+t_{i r}^{C d}\right)^{1-\sigma_{i}^{d}}\left(P_{i r}^{Y}\right)^{1-\sigma_{i}^{d}}+\left(1-\theta_{i r}^{C}\right)\left(1+t_{i r}^{C m}\right)^{1-\sigma_{i}^{d}}\left(P_{i r}^{m}\right)^{1-\sigma_{i}^{d}}\right)^{\frac{1}{1-\sigma_{i}^{d}}}
\end{gathered}
$$

The solution to the dual optimization problem with the expenditure functions yields the demand functions for final private demand of domestic and imported goods, so the market equilibrium for these goods are:

$$
\begin{aligned}
C_{r}^{p r i v}\left(\frac{\partial P C_{r} C_{r}^{p r i v}}{\partial P_{i r}^{Y}}\right) & =C_{i r}^{C d} \\
C_{r}^{p r i v}\left(\frac{\partial P C_{r} C_{r}^{p r i v}}{\partial P_{i r}^{m}}\right) & =C_{i r}^{C m}
\end{aligned}
$$

\section{A.3. Public Sector}

Public consumption is represented through a Leontief nested function:

$$
\begin{gathered}
G_{r}^{p u b}=\min \left(G_{1 r}^{G}, \ldots, G_{7 r}^{G}\right) \\
G_{i r}^{G}=\left(\theta_{i r}^{G d}\left(G_{i r}^{G d}\right)^{1-\sigma_{i}^{d}}+\left(1-\theta_{i r}^{G d}\right)\left(G_{i r}^{G m}\right)^{1-\sigma_{i}^{d}}\right)^{\frac{1}{1-\sigma_{i}^{d}}}
\end{gathered}
$$


where, subject to the budget constraints:

$$
I N C O M E_{r}^{p u b}-P G_{r} G_{r}^{p u b}=P U B S A V_{r}
$$

$I N C O M E_{r}^{p u b}=R E V_{r}^{O}+R E V_{r}^{f d}+R E V_{r}^{f m}+R E V_{r}^{f}+R E V_{r}^{C d}+R E V_{r}^{C m}+R E V_{r}^{G d}+R E V_{r}^{G m}+R E V_{r}^{I d}+R E V_{r}^{I m}+R E V_{r}^{m s}-R E V_{r}^{x s}$ where the different revenues, denoted by $R E V$, come from several taxes:

$$
\begin{aligned}
& R E V_{r}^{O}=\sum_{i=1}^{7} t_{i r}^{O} P_{i r}^{Y} Y_{i r} \\
& R E V_{r}^{f d}=\sum_{i=1}^{7} \sum_{j=1}^{7} t_{i j r}^{f d} P_{i r}^{Y} I I_{i j r}^{Y} \\
& R E V_{r}^{f m}=\sum_{i=1}^{7} \sum_{j=1}^{7} t_{i j r}^{f m} P_{i j r}^{m} I I_{i j r}^{m}
\end{aligned}
$$

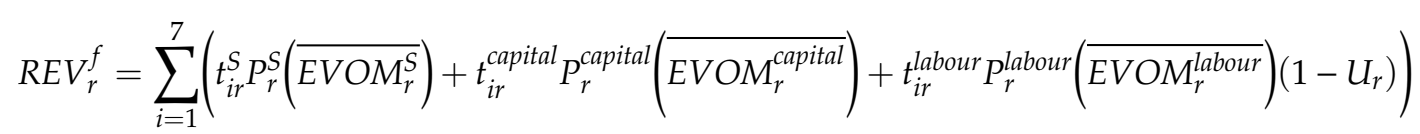

$$
\begin{aligned}
& R E V_{r}^{C d}=\sum_{i=1}^{7} t_{i r}^{C d} P_{i r}^{Y} C_{i r}^{C d} \\
& R E V_{r}^{C m}=\sum_{i=1}^{7} t_{i r}^{C m} P_{i r}^{m} C_{i r}^{C m} \\
& R E V_{r}^{G d}=\sum_{i=1}^{7} t_{i r}^{G d} P_{i r}^{Y} G_{i r}^{G d} \\
& R E V_{r}^{G m}=\sum_{i=1}^{7} t_{i r}^{G m} P_{i r}^{m} G_{i r}^{G m} \\
& R E V_{r}^{I d}=\sum_{i=1}^{7} t_{i r}^{I d} P_{i r}^{Y} I_{i r}^{I d} \\
& R E V_{r}^{I m}=\sum_{i=1}^{7} t_{i r}^{I m} P_{i r}^{m} I_{i r}^{I m} \\
& R E V_{r}^{m s}=\sum_{i=1}^{7} \sum_{s=1}^{13} t_{i s r}^{m s}\left(P_{i s}^{Y}\left(1-t_{i s r}^{x s}\right) E X P_{i s r}+\sum_{j=1}^{7} P_{j i s r}^{t} T R N_{j i s r}\right) \\
& s \neq r \\
& R E V_{r}^{x s}=\sum_{i=1}^{7} \sum_{\substack{s=1 \\
s \neq r}}^{13} t_{i r s}^{x s} P_{i r}^{Y} E X P_{i r s}
\end{aligned}
$$

and:

$$
P G_{r} G_{r}^{p u b}=\sum_{i=1}^{7} P_{i r}^{G} G_{i r}^{G}
$$




$$
\begin{gathered}
P_{i r}^{G}=\left(\theta_{i r}^{G d}\left(1+t_{i r}^{G d}\right)^{1-\sigma_{i}^{d}}\left(P_{i r}^{Y}\right)^{1-\sigma_{i}^{d}}+\left(1-\theta_{i r}^{G d}\right)\left(1+t_{i r}^{G m}\right)^{1-\sigma_{i}^{d}}\left(P_{i r}^{m}\right)^{1-\sigma_{i}^{d}}\right)^{\frac{1}{1-\sigma_{i}^{d}}} \\
\text { PUBSAV } V_{r}=P_{r} C_{r}^{\text {pubsav }}
\end{gathered}
$$

The solution to the dual optimization problem with the expenditure functions yields the demand functions for final public demand of domestic and imported goods used in the next equation conditions:

$$
\begin{aligned}
& G_{r}^{p u b}\left(\frac{\partial P G_{r} G_{r}^{p u b}}{\partial P_{i r}^{Y}}\right)=G_{i r}^{G d} \\
& G_{r}^{p u b}\left(\frac{\partial P G_{r} G_{r}^{p u b}}{\partial P_{i r}^{m}}\right)=G_{i r}^{G m}
\end{aligned}
$$

\section{A.4. Investment and Savings}

The aggregate gross capital formation enters the model as an exogenous component of final demand. It can be interpreted in this static framework as a component of final demand representing future consumption:

$$
\overline{I_{r}}=\min \left(I_{1 r}^{I}, \ldots, I_{7 r}^{I}\right)
$$

where:

$$
I_{i r}^{I}=\left(\theta_{i r}^{I d}\left(I_{i r}^{I d}\right)^{1-\sigma_{i}^{d}}+\left(1-\theta_{i r}^{I d}\right)\left(I_{i r}^{I m}\right)^{1-\sigma_{i}^{d}}\right)^{\frac{1}{1-\sigma_{i}^{d}}}
$$

subject to:

$$
\begin{gathered}
\text { PRIVSAV } V_{r}+\text { PUBSAV }_{r}+P C_{n u m} V B_{r}=P I_{r} \bar{I}_{r} \\
P I_{r} \bar{I}_{r}=\sum_{i=1}^{7} P I_{i r} I_{i r}^{I} \\
P I_{i r}^{I}=\left(\theta_{i r}^{I d}\left(1+t_{i r}^{I d}\right)^{1-\sigma_{i}^{d}}\left(P_{i r}^{Y}\right)^{1-\sigma_{i}^{d}}+\left(1-\theta_{i r}^{I d}\right)\left(1+t_{i r}^{I m}\right)^{1-\sigma_{i}^{d}}\left(P_{i r}^{m}\right)^{1-\sigma_{i}^{d}}\right)^{\frac{1}{1-\sigma_{i}^{d}}}
\end{gathered}
$$

The solution to the dual optimization problem yields the demand for gross domestic formation of domestic $\left(I_{i r}^{I d}\right)$ and imported goods $\left(I_{i r}^{I m}\right)$ :

$$
\begin{aligned}
& \overline{I_{r}}\left(\frac{\partial P I_{r} \overline{I_{r}}}{\partial P_{i r}^{Y}}\right)=I_{i r}^{I d} \\
& \overline{I_{r}}\left(\frac{\partial P I_{r} \overline{I_{r}}}{\partial P_{i r}^{m}}\right)=I_{i r}^{I m}
\end{aligned}
$$

\section{A.5. Foreign Sector}

The choice among imports from several sources involves the maximization of the Armington aggregate subject to the foreign sector constraints (or the dual problem, i.e., minimization of the cost of the Armington aggregate). The Armington aggregate is:

$$
I M P_{i r}=\left(\sum_{s} \theta_{i s r}^{m}\left(E X P A_{i s r}\right)^{1-\sigma_{i}^{m}}\right)^{\frac{1}{1-\sigma_{i}^{m}}}
$$

where:

$$
E X P A_{i s r}=\min \left(E X P_{i s r}, T R M_{j i s r}\right) j=T R N
$$




$$
\sum_{i=1}^{7} \sum_{\substack{r=1 \\ r \neq s}}^{13} \sum_{\substack{s=1 \\ s \neq r}}^{13} T_{R} M_{j i s r}=\sum_{r=1}^{13} \theta_{j}^{T} Y_{j r}
$$

The constraints related to the foreign sector in this open economy are:

$$
\sum_{i=1}^{7} \sum_{\substack{s=1 \\ s \neq r}}^{13} P t_{i s r}^{m} E X P A_{i s r}+P C_{n u m} V B_{r}=\sum_{i=1}^{7} P_{i r}^{m} I M P_{i r}
$$

where:

$$
\begin{gathered}
P t_{i s r}^{m}=\theta_{i s r}^{m} P_{i s r}+\sum_{j} \theta_{j}^{T} P_{j i s r}^{t} \\
P_{i s r}=P_{i s}^{Y}\left(1-t_{i s r}^{x s}\right)\left(1+t_{i s r}^{m s}\right) \\
P_{j i s r}^{t}=P_{j}^{T}\left(1+t_{i s r}^{m s}\right) \\
P_{j}^{T}=\prod_{r=1}^{13}\left(P_{j r}^{Y}\right)^{\theta_{r}^{T}} \\
P_{i r}^{m}=\left(\sum_{s} \theta_{i s r}^{m}\left(P_{i s r}\right)^{1-\sigma_{i}^{m}}\right)^{\frac{1}{1-\sigma_{i}^{m}}}
\end{gathered}
$$

The world equilibrium involves that national trade balances cancel out:

$$
\sum_{r=1}^{13} P C_{n u m} V B_{r}=0
$$

A.6. Labour Market Constraint

The equilibrium in the labour market is given by the previously shown market clearing condition:

$$
\sum_{i=1}^{7}\left(Y_{i r}\left(\frac{\partial P R O F I T_{i r}^{Y}}{\partial P_{r}^{\text {labour }}}\right)\right)=\overline{\operatorname{EVOM}_{r}^{\text {labour }}}\left(1-U_{r}\right)
$$

and the restriction related to unemployment:

$$
\frac{P_{r}^{\text {labour }}}{P C_{r}}=\left(\frac{U_{r}}{\overline{U_{r}}}\right)^{\beta}
$$

where $\beta<0$.

\section{A.7. Simulations}

In the main text, we perform three simulations in order to reach a level of real government expenditure in health services of $20 \%$ of the total public expenditure for all countries except Rest of the World. These simulations involve some changes in the previous equations, which are as follows (recall that, in each simulation, "country $r$ " refers to all countries except Rest of the World).

(1) Scenario of endogenous government deficit in country $r$, holding all tax rates constant. The parameter ADJUST $_{r}$ is 1 at the benchmark and takes a lower value in the simulation, so that the new expanded 
real public expenditure $G_{r}^{\text {pub* }}$ increases. This increase leads to a decrease in public savings PUBSA $V_{r}$ since tax rates do not change, even though the public income $I N C O M E_{r}^{\text {pub }}$ can change endogenously:

$$
I N C O M E_{r}^{p u b}-P G_{r} G_{r}^{p u b *}=P U B S A V_{r}^{\text {adjust }}
$$

where:

$$
\begin{gathered}
G_{r}^{\text {pub* }}=\min \left(\overline{G_{1 r}^{G}}, \ldots, G_{6 r}^{G}, \overline{G_{7 r}^{G}}\right) \\
\text { PUBSA } V_{r}^{\text {adjust }}=\text { ADJUSTr PUBSA } V_{r}
\end{gathered}
$$

The new level of public expenditure in different goods is fixed exogenously $\left(\bar{G}_{i r}^{G} ; i=1, \ldots, 7 ; i \neq 6\right)$, except for the health services (included at $G_{6 r}^{G}$ ). So $G_{r}^{p u b *}$ is the new total public expenditure which is also endogenous. Public health services change endogenously until reaching the targeted $20 \%$.

(2) Scenario of increase in direct taxes on labour in country $r$, with an increased public expenditure in health services. The variable ADJUST $T_{r}$ is 1 at the benchmark and takes a value above 1 in the simulation, so that the benchmark ad valorem labour tax rates rise. Public savings $\overline{P U B S A V_{r}}$ remain constant, even though the public income $I N C O M E_{r}^{\text {pub }}$ can change endogenously:

$$
\begin{aligned}
& P_{i r}^{f}=\left(\sum_{f} \theta_{i r}^{f}\left(P_{i r}^{p f}\right)^{1-\sigma_{i}^{V A}}\right)^{\frac{1}{1-\sigma_{i}^{V A}}} \\
& P_{i r}^{p f}=\left\{\begin{array}{c}
P_{r}^{\text {labour }}\left(1+\text { ADJUST }_{r} r_{i r}^{\text {labour }}\right) \\
P_{r}^{\text {capital }}\left(1+t_{i r}^{\text {capital }}\right) \\
P_{r}^{S}\left(1+t_{i r}^{S}\right)
\end{array}\right. \\
& R E V_{r}^{f}=\sum_{i=1}^{7}\left(t_{i r}^{S} P_{r}^{S}\left(\overline{E V O M_{r}^{S}}\right)+t_{i r}^{\text {capital }} P_{r}^{\text {capital }}\left(\overline{\operatorname{EVOM}_{r}^{\text {capital }}}\right)+\operatorname{ADJUST}_{r} t_{\text {irr }}^{\text {labour }} P_{r}^{\text {labour }}\left(\overline{\operatorname{EVOM}_{r}^{\text {labour }}}\right)\left(1-U_{r}\right)\right) \\
& I N C O M E_{r}^{p u b}-P G_{r} G_{r}^{p u b *}=\overline{P U B S A V_{r}}
\end{aligned}
$$

where:

$$
G_{r}^{p u b *}=\min \left(\overline{G_{1 r}^{G}}, \ldots, G_{6 r}^{G}, \overline{G_{7 r}^{G}}\right)
$$

Again, the new level of public expenditure in different goods is fixed exogenously $\left(\overline{G_{i r}^{G}} ; i=1, \ldots, 7 ; i \neq 6\right)$, except for the health services (included at $\left.G_{6 r}^{G}\right)$. So $G_{r}^{p u b *}$ is the new total public expenditure which is also endogenous. Public health services change endogenously until reaching the targeted $20 \%$.

(3) Scenario of increase in indirect taxes in country $r$, with an increased public expenditure in health services. The variable $A D J U S T_{r}$ is 1 at the benchmark and takes a value above 1 in the simulation, so that the benchmark ad valorem indirect tax rates rise. Public savings $\overline{P U B S A V_{r}}$ remain constant, even though the public income INCOME $E_{r}^{\text {pub }}$ can change endogenously:

$$
\begin{gathered}
P_{i r}^{C}=\left(\theta_{i r}^{C}\left(1+\text { ADJUST }_{r} t_{i r}^{C d}\right)^{1-\sigma_{i}^{d}}\left(P_{i r}^{Y}\right)^{1-\sigma_{i}^{d}}+\left(1-\theta_{i r}^{C}\right)\left(1+\text { ADJUST }_{r} t_{i r}^{C m}\right)^{1-\sigma_{i}^{d}}\left(P_{i r}^{m}\right)^{1-\sigma_{i}^{d}}\right)^{\frac{1}{1-\sigma_{i}^{d}}} \\
R E V_{r}^{C d}=\sum_{i=1}^{7} A^{2} \operatorname{AJUST}_{r} t_{i r}^{C d} P_{i r}^{Y} C_{i r}^{C d}
\end{gathered}
$$




$$
\begin{gathered}
R E V_{r}^{C m}=\sum_{i=1}^{7} \text { ADJUST }_{r} t_{i r}^{C m} P_{i r}^{m} C_{i r}^{C m} \\
I N C O M E_{r}^{p u b}-P G_{r} G_{r}^{p u b *}=\overline{\text { PUBSAV }}
\end{gathered}
$$

where:

$$
G_{r}^{p u b *}=\min \left(\overline{G_{1 r}^{G}}, \ldots, G_{6 r}^{G}, \overline{G_{7 r}^{G}}\right)
$$

As in the previous simulations, the new level of public expenditure in different goods is fixed exogenously $\left(\overline{G_{i r}^{G}} ; i=1, \ldots, 7 ; i \neq 6\right)$, except for the health services (included at $\left.G_{6 r}^{G}\right)$. So $G_{r}^{p u b *}$ is the new total public expenditure which is also endogenous. Public health services change endogenously until

\begin{tabular}{|c|c|}
\hline Symbol & Definition \\
\hline ADJUST $_{r}$ & Adjustments in simulations, for country $r$ (benchmark $=1$ ) \\
\hline$C^{C}$ & Final private consumption of good $i$ in country $r$ \\
\hline$C_{i r}^{C m}$ & Final private consumption of good $i$ in country $r$, origin imports \\
\hline$C_{r}^{\text {priv }}$ & Aggregate final private consumption in country $r$ \\
\hline$C_{r}^{\text {pubsav }}$ & Aggregate public savings in country $r$ \\
\hline$E X P A_{\text {irs }}$ & Exports of good $i$ from country $r$ to country s, including transportation margins \\
\hline$G_{i r}^{G}$ & Final public consumption of good $i$ in country $r$ \\
\hline$G_{i r}^{i r}$ & Final public consumption of good $i$ in country $r$, origin domestic production \\
\hline$G_{i r}^{i r m}$ & Final public consumption of good $i$ in country $r$, origin imports \\
\hline$G_{r}^{i r}$ & Aggregate final public consumption in country $r$ \\
\hline$I_{i r}^{I m}$ & Investment (gross capital formation) in goods produced by sector $i$ in country $r$, origin imports \\
\hline$I I_{i j r}$ & Intermediate inputs from sector $j$ used by good $i$ in country $r$ \\
\hline$I I_{r}^{i}$ & Aggregate intermediate inputs used by good $i$ in country $r$ \\
\hline$I I_{i j r}^{Y}$ & Intermediate inputs from sector $j$ used by good $i$ in country $r$, origin domestic production \\
\hline$I I_{i j r}^{m}$ & Intermediate inputs from sector $j$ used by good $i$ in country $r$, origin imports \\
\hline$I M P_{i r}$ & Imports of good i in country $r$ \\
\hline$I N C O M E_{r}^{p r i v}$ & Private income in country $r$ \\
\hline$I N C O M E_{r}^{p u b}$ & Public income in country $r$ \\
\hline$P_{i s r}$ & Price (unit cost) of good $i$ exported from country $s$ to country $r$, excluding transportation margins \\
\hline$P_{j}^{C}$ & Price (unit cost) for private consumption of good $i$ in country $r$ \\
\hline$P_{i r}^{m}$ & Price (unit cost) for good $i$ imported and used in country $r$ \\
\hline$P_{j}^{p r}$ & Price (unit cost) for factor $p f$ (= labour, capital, specific) used in good $i$ in country $r$ \\
\hline $\begin{array}{l}i r \\
P_{r}^{S}\end{array}$ & Price (unit cost) for specific factor $S$ in country $r$ \\
\hline$P_{j}^{T}$ & World price (unit cost) for transportation margins $(j=T R N)$ \\
\hline$P_{j i s r}^{t}$ & Price (unit cost) for international transportation $(j=T R N)$ margins in good $i$ traded from country $s$ to country $r$, including tariffs \\
\hline$P_{i r}^{Y}$ & Price (unit cost) for good $Y_{i r}$ \\
\hline$P C_{\text {num }}$ & Price (unit cost) for aggregate final private consumption in numeraire country \\
\hline$P C_{r}$ & Price (unit cost) for aggregate final private consumption in country $r$ \\
\hline$P G_{r}$ & Price (unit cost) for aggregate final public consumption in country $r$ \\
\hline$P I_{r}$ & Price (unit cost) for aggregate savings in country $r$ \\
\hline$P t_{i s r}^{m}$ & Price (unit cost) of exports from country $s$ to country $r$, including transportation margins \\
\hline PRIVSAV ${ }_{r}$ & Private savings in country $r$ \\
\hline
\end{tabular}
reaching the targeted $20 \%$.

Table A1. Endogenous variables. 
Table A1. Cont.

\begin{tabular}{|c|c|}
\hline Symbol & Definition \\
\hline PROFIT Y & Unit profits for $Y_{i r}$ \\
\hline PUBSAV $V_{r}$ & Public savings in country $r$ \\
\hline$R E V_{r}^{C d}$ & Revenue in country $r$ from taxes on final private consumption of domestic goods \\
\hline$R E V_{r}^{C m}$ & Revenue in country $r$ from taxes on final private consumption of imports \\
\hline$R E V_{i}^{f}$ & Revenue in country $r$ from factor taxes \\
\hline$R E V_{r}^{f m}$ & Revenue in country $r$ from taxes on imported intermediate inputs \\
\hline$R E V_{r}^{G d}$ & Revenue in country $r$ from taxes on final public consumption of domestic goods \\
\hline$R E V_{r}^{G m}$ & Revenue in country $r$ from taxes on final public consumption of imported goods \\
\hline$R E V_{r}^{I d}$ & Revenue in country $r$ from taxes on investment of domestic goods \\
\hline$R E V_{r}^{I m}$ & Revenue in country $r$ from taxes on investment of imported goods \\
\hline$T R M_{j i s r}$ & Transportation $(j=T R N)$ margin for good $i$ exported from country $s$ to country $r$ \\
\hline$U_{r}$ & Unemployment rate in country $r$ \\
\hline$V A_{r}^{i}$ & Aggregate value added used by good $i$ in country $r$ \\
\hline$V B_{r}$ & Foreign savings in country $r$ \\
\hline$Y_{i r}$ & Quantity of good $i$ produced in country $r$ \\
\hline
\end{tabular}

Table A2. Exogenous variables and parameters.

\begin{tabular}{|c|c|}
\hline Symbol & Definition \\
\hline$\overline{C_{r}^{\text {privsav }}}$ & Aggregate private savings in country $r$ \\
\hline$\overline{E V M_{r}^{\text {capital }}}$ & Capital endowment in country $r$ \\
\hline$\overline{E V O M}$ labour & Labour endowment in country $r$ \\
\hline$\overline{E V O M_{r}^{S}}$ & Specific factor $S$ endowment in country $r$ \\
\hline$\overline{G_{11 r}^{G}}$ & Counterfactual public expenditure in health and social services in country $r$ \\
\hline$\overline{I_{r}}$ & Aggregate gross capital formation in country $r$ \\
\hline$\overline{U_{r}}$ & Benchmark unemployment rate \\
\hline$t_{j r}^{\text {capital }}$ & Taxes on capital for good $i$ in country $r$ \\
\hline$t_{i r}^{c d}$ & Taxes on private consumption for good $i$ in country $r$, origin domestic production \\
\hline$t_{i r}^{\mathrm{Cm}}$ & Taxes on private consumption for good $i$ in country $r$, origin imports \\
\hline$t_{i r}^{F}$ & Taxes on factor $F$ (=labour, capital) for good $i$ in country $r$ \\
\hline$t_{i j r}^{f d}$ & Taxes on domestic intermediate input $j$ for good $i$ in country $r$ \\
\hline$t_{i j r}^{f m}$ & Taxes on imported intermediate input $j$ for good $i$ in country $r$ \\
\hline$t_{i r}^{G d}$ & Taxes on public consumption for good $i$ in country $r$, origin domestic production \\
\hline$t_{i r}^{G m}$ & Taxes on public consumption for good $i$ in country $r$, origin imports \\
\hline$t_{i r}^{I d}$ & Taxes on investment for good $i$ in country $r$, origin domestic production \\
\hline$t_{i r}^{I m}$ & Taxes on investment for good $i$ in country $r$, origin imports \\
\hline$t_{\text {ir }}^{\text {labour }}$ & Taxes on labour for good $i$ in country $r$ \\
\hline$t_{i s r}^{m s}$ & Tariff for good $i$ exported from country $s$ to country $r$ \\
\hline$t_{i r}^{O}$ & Output taxes for good $i$ in country $r$ \\
\hline$t_{i r}^{S}$ & Taxes on specific factor $S$ for good $i$ in country $r$ \\
\hline$t_{i s r}^{x s}$ & Export subsidy for good $i$ exported from country $s$ to country $r$ \\
\hline$\beta$ & Parameter of flexibility of the real wage to the unemployment rate \\
\hline$\theta$ & Share parameters \\
\hline$\sigma_{i}^{d}$ & Armington elasticity of substitution domestic-imported components in good $i$ \\
\hline$\sigma_{i}^{m}$ & Armington elasticity of substitution among imported components in good $i$ \\
\hline$\sigma_{i}^{V A}$ & Elasticity of substitution among factors in good $i$ \\
\hline
\end{tabular}




\section{References}

1. United Nations. Transforming Our World: The 2030 Agenda for Sustainable Development; United Nations: New York, NY, USA, 2015.

2. Bajo-Rubio, O.; Gómez-Plana, A.G. Spending in Social Services in China: A Multi-Country Analysis, GLO Discussion Paper, 447; Global Labor Organization: Essen, Germany, 2020.

3. World Health Organization. WHO Guide to Identifying the Economic Consequences of Disease and Injury; World Health Organization: Geneva, Switzerland, 2009.

4. Shoven, J.B.; Whalley, J. Applying General Equilibrium; Cambridge University Press: Cambridge, UK, 1992.

5. Dixon, P.B.; Jorgenson, D.W. Handbook of Computable General Equilibrium; Elsevier: Amsterdam, The Netherlands, 2013.

6. Burfisher, M.E. Introduction to General Equilibrium Models, 2nd ed.; Cambridge University Press: Cambridge, UK, 2016.

7. Xu, K.; Saksena, P.; Holly, A. The Determinants of Health Expenditure: A Country-Level Panel Data Analysis, Working Paper; Results for Development Institute (R4D): Washington, DC, USA, 2011.

8. Lanz, B.; Rutherford, T.F. GTAPinGAMS: Multiregional and small open economy models. J. Glob. Econ. Anal. 2016, 1, 1-77. [CrossRef]

9. Mathiesen, L. Computation of economic equilibria by a sequence of linear complementarity problems. Mathematical Programming Study 1985, 23, 144-162.

10. Rutherford, T.F. Applied general equilibrium modeling with MPSGE as a GAMS subsystem: An overview of the modeling framework and syntax. Comput. Econ. 1999, 14, 1-46. [CrossRef]

11. Narayanan, G.B.; Aguiar, A.; McDougall, R. Global Trade, Assistance, and Production: The GTAP 9 Data Base; Center for Global Trade Analysis, Purdue University: West Lafayette, IN, USA, 2015.

12. United Nations. National Accounts Statistics: Main Aggregates and Detailed Tables, 2013; United Nations: New York, NY, USA, 2014.

13. World Health Organization. Global Health Observatory (GHO) Data Repository; World Health Organization: Geneva, Switzerland, 2020.

14. Armington, P.S. A theory of demand for products distinguished by place of production. IMF Staff Papers 1969, 16, 159-178. [CrossRef]

15. Blanchflower, D.G.; Oswald, A.J. The Wage Curve; The MIT Press: Cambridge, MA, USA, 1994.

16. Dervis, K.; de Melo, J.; Robinson, S. A general equilibrium analysis of foreign exchange shortages in a developing economy. Econ. J. 1981, 91, 891-906. [CrossRef]

17. Blanchflower, D.G.; Oswald, A.J. An introduction to the wage curve. J. Econ. Perspect. 1995, 9, $153-167$. [CrossRef]

18. World Bank. World Development Indicators 2011; World Bank: Washington, DC, USA, 2015.

19. Rudra, N. Welfare states in developing countries: Unique or universal? J. Politics 2007, 69, 378-396. [CrossRef]

20. Bloom, D.E.; Canning, D.; Sevilla, J. The effect of health on economic growth: A production function approach. World Dev. 2004, 32, 1-13. [CrossRef]

21. Novignon, J.; Olakojo, S.A.; Nonvignon, J. The effects of public and private health care expenditure on health status in sub-Saharan Africa: New evidence from panel data analysis. Heal. Econ. Rev. 2012, 2, 22. [CrossRef] [PubMed]

22. Torój, A. Why don't Blanchard-Kahn ever "catch" flu? And how it matters for measuring indirect cost of epidemics in DSGE framework. Cent. Eur. J. Econ. Model. Econ. 2013, 5, 185-206.

(C) 2020 by the authors. Licensee MDPI, Basel, Switzerland. This article is an open access article distributed under the terms and conditions of the Creative Commons Attribution (CC BY) license (http://creativecommons.org/licenses/by/4.0/). 